\title{
BASES ONTOLÓGICAS DA SAÚDE DAS MULHERES NEGRAS1
}

\author{
Diego de Oliveira Souza² \\ Roberta Dayanne de Oliveira Santos ${ }^{3}$
}

Resumo: Analisa-se a saúde das mulheres negras a partir de uma perspectiva ontológica. Parte-se da premissa de que a saúde é determinada socialmente, o que confere eminência às questões "racial" e da mulher, porém sem autonomia absoluta ante a esfera econômica. Configura-se um prolixo processo social no qual os vários componentes se determinam reciprocamente, mas sobre as mesmas bases materiais. Enfrentar as formas particulares de desigualdade social se mostra importante para a esfera da saúde e, sobretudo, para a construção dos caminhos de emancipação do "gênero humano".

Palavras-chave: Determinação Social da Saúde; Etnia; Gênero; Gênero Humano.

\begin{abstract}
The health of black women is analyzed from an ontological perspective. Health is considered as a process determined socially, which gives eminence to the issues of "race" and women, but without absolute autonomy in relation to the economic sphere. A complex social process is established which the various components are determined reciprocally, but on the same material basis. Facing particular forms of social inequality is important for the health sphere and, above all, for the construction of the ways of emancipation of the "human gender".
\end{abstract}

Keywords: Social Determination of Health; Ethnicity; Gender; Human Gender.

\section{INTRODUÇÃO}

O debate sobre as questões "racial"3 e da mulher tem avançado nos últimos anos, gerando tensões no interior da cultura predominante. Tais avanços são, decerto, importantes, pois têm se dado no campo da cultura, da educação, das relações subjetivas entre os sujeitos, do direito etc., possibilitando melhorias

\footnotetext{
${ }_{1}^{1}$ DOI: https://doi.org/10.22409/tn.15i27.p9634

${ }^{2}$ Doutor em Serviço Social pela Uerj. Mestre em Serviço Social pela Ufal. Especialista em Saúde do Trabalhador pela Fatec Internacional. Graduado em Enfermagem pela Ufal. Professor Adjunto e Enfermagem. E-mail: enfufaldiego@hotmail.com. Endereço: Av. Nossa Senhora de Fátima, $\mathrm{n}$. 145, Bairro Alto do Cruzeiro, CEP: 57313-040, Arapiraca/AL.

${ }^{3}$ Mestranda em Antropologia Social pela Ufal. Graduada em Enfermagem pela Ufal. E-mail: r.dayanne@hotmail.com.

${ }^{4}$ Ao longo do texto argumentaremos contra o uso do termo "racial".
} 
parciais na vida das mulheres negras, embora muito se tenha ainda de avançar nos campos mencionados.

Apesar disso, a nosso ver, por vezes, o debate (seja político-social, seja científico) tem se afastado ou até mistificado as bases materiais (de cunho ontológico) das questões, fazendo-nos perder de vista a articulação que existe entre elas e a exploração da classe trabalhadora (desconsiderando o processo de produção/reprodução do capital). Isso tem implicação direta nas estratégias de enfrentamento dos problemas sociais que se desdobram das questões ora em foco, como, por exemplo, contra o "racismo" ou a "desigualdade de gênero", uma vez que deixa intactas suas raízes, limitando-se a corrigir seus efeitos.

Com isso, ainda se mantém um cenário de desigualdades que assume formas particulares (mais graves e mais complexas) nesses grupos sociais: negros e mulheres. Tal condição está explicitada em indicadores sociais. Por exemplo, segundo o Instituto de Pesquisa Econômica Aplicada - Ipea (2014, p. 15, grifos da obra), no Brasil, "os negros possuem nível de renda per capita familiar menor que os brancos, sendo mais numerosos nas faixas de rendimento com menos de 0,5 salário-mínimo de renda mensal per capita familiar". Além disso, em geral, as famílias "chefiadas" por negros(as) ocupam um maior número de moradias classificadas como inadequadas ${ }^{4}$ do que aquelas chefiadas por brancos(as). Isso fica demonstrado ao se analisar a distribuição de moradias no ambiente urbano metropolitano, onde $77,1 \%$ das moradias da população branca são classificadas como adequadas, contra apenas $60,9 \%$ das habitações de famílias negras (IPEA, 2014).

A escolaridade é outro fator relevante: "considerando a população com mais de 15 anos, em 2012, 23\% da população branca tinha menos de quatro anos de estudo; entre os negros, este percentual atingiu 32,3\%" (IPEA, 2014, p. 19). Já quando observamos a composição das famílias (e, nesse caso, considerando a simbiose entre questão "racial" e de "gênero"), observa-se que

\footnotetext{
${ }^{4}$ A moradia classificada como adequada é aquela que consiste em "construção de alvenaria ou madeira tratada, com telhas ou lajes; acesso à água potável com canalização, coleta de esgoto e lixo; máximo de duas pessoas por dormitório com banheiro no domicílio; e acesso à telefonia e eletricidade". Aquelas que não atendem a todos esses requisitos, são tidas como inadequadas (IPEA, 2014, p. 17).
}

TrabalhoNecessario - www.uff.br/trabalhonecessario; Ano 15, № 27/2017 
existem mais famílias formadas apenas por mulher e filhos entre a população negra, sendo o percentual de $17,6 \%$, contra $14,8 \%$ entre os brancos (IPEA, 2014).

Ao se comparar homens e mulheres em geral, constata-se que elas ainda trabalham mais e recebem menos. Consoante revelam Atal, Nopo e Winder (2009), as mulheres brasileiras trabalham cerca de cinco horas a mais que os homens e recebem aproximadamente $30 \%$ menos. Ademais, considerando a população acima de 25 anos, vê-se que 6,7\% dos homens ocupavam cargos de chefia ou direção, contra apenas 4,7\% das mulheres. Esses dados revelam que, ainda hoje, existem disparidades entre homens e mulheres, o que implica maiores dificuldades sociais para estas.

Obviamente, a situação social da mulher negra corrobora os péssimos indicadores sociais acima mencionados. Sua condição de saúde é exemplar da atuação sinérgica entre os vários elementos sociais que compõem seu panorama atual. A título de exemplo, segundo a Coordenação Nacional de Hipertensão e Diabetes, em 2009, cerca de $27 \%$ das mulheres brasileiras tinham hipertensão arterial sistêmica (HAS), enquanto entre homens a taxa era de $21 \%$. Quando observada a taxa apenas entre as mulheres negras, o indicador é ainda mais grave, porquanto negras tenham quatro vezes mais HAS do que as mulheres brancas (SILVA NASCIMENTO; SARDINHA; PEREIRA, 2012). Para Santos (2008), mulheres negras ainda são mais acometidas por diabetes e, entre a população negra geral, predominam problemas como anemia falciforme, desnutrição, tuberculose e morbimortalidade por causas externas (violência).

Fica clara a relação entre as problemáticas sociais enfrentadas por essas mulheres e sua saúde. Trata-se de um panorama construído históricosocialmente, assumindo significativa complexidade quando comparado a outros grupos sociais. Diante disso, nosso objetivo consiste em realizar uma análise ontológica da saúde das mulheres negras, buscando resgatar as determinações preponderantes (materiais) desse processo social. Para tanto, nossa investigação apreende três importantes mediações de análise: a determinação social da saúde em geral, a questão "racial" e a questão da mulher, articuladas em um plano de fundo comum. 
Para tanto, cabe fazer uma ressalva do ponto de vista teóricometodológico: a análise desenvolvida neste artigo orienta-se pela perspectiva histórico-ontológica, de cariz marxiano. Portanto, nem se guia pela especulação metafísica das ontologias antigas e medievais, nas quais a essência dos processos sociais era tida como predeterminada e, por isso, imutável; nem se limita à fugacidade dos epifenômenos, supervalorizando a dimensão subjetiva das relações sociais. A ontologia marxiana, tão bem explicitada por Lukács (2012; 2013), ancora-se na relação dialética entre aparência e essência, com determinações recíprocas, reconhecendo, sobretudo, que a própria essência é radicalmente histórica, ainda que possua elementos de maior continuidade que a esfera fenomênica. Assim, o problema da essência se resolve na própria dinamicidade das relações sociais, quando as esferas subjetiva e objetiva se entrelaçam, com determinação predominante desta sobre aquela.

Destarte, realiza-se aqui uma decomposição analítico-abstrata do objeto de estudo, no sentido de explicitar as bases materiais de cada uma das mediações há pouco mencionadas, para depois reconstruí-lo, a fim de demonstrar, em linhas gerais, as raízes da questão da saúde das mulheres negras. Convém esclarecer que os dados e o percurso histórico da realidade brasileira foram tomados como particularidades de análise, permitindo o desencadear da discussão. Com isso, espera-se contribuir para o que debate se amplie, numa direção que articule suas diversas dimensões, sem perder de vista suas determinações mais profundas.

\section{A DETERMINAÇÃO SOCIAL DA SAÚDE}

O entendimento sobre a natureza do processo saúde-doença perpassou várias perspectivas na história. $\mathrm{Na}$ verdade, a saúde só passa a ser entendida como processo mais recentemente (décadas de 1960, 1970 e 1980), quando da aproximação entre Ciências da Saúde e as tendências mais dialéticas das Ciências Sociais. Antes disso, compreendia-se a saúde como fenômeno sobrenatural (Idade Antiga e Medieval), apenas na sua dimensão biológica (modelo biomédico vigente a partir da modernidade) ou, mesmo após as 
contribuições da Organização Mundial da Saúde (OMS) e seu novo conceito de saúde, sem perceber a dinamicidade inerente à saúde 5 .

A partir das contribuições do Movimento Operário Italiano (décadas de 1960 e 1970), inicia-se o estabelecimento das correlações entre adoecimento e a forma de trabalho determinada pelo modo de produção capitalista. Macaccaro (1980) enfatiza a imprescindibilidade da luta de classes para os enfrentamentos dos problemas de saúde. Concomitantemente, mas com maior ênfase, nos fins da década de 1970 e na de 1980, a Medicina Social latino-americana traz contribuições decisivas para consolidar a perspectiva da saúde como processo social.

Representante desse campo, Laurell (1982, p. 16) esclarece que:

Em termos muito gerais, o processo saúde-doença é determinado pelo modo como o homem se apropria da natureza em um dado momento, apropriação que se realiza por meio de processo de trabalho baseado em determinado desenvolvimento das forças produtivas e relações sociais de produção.

Com efeito, avança-se no sentido de que a saúde, enquanto processo social, possui o trabalho como determinação essencial (embora não a única), conferindo-Ihe a natureza eminentemente social, apesar de se expressar biologicamente. Sobre isso, Rezende (1989, p. 87) assinala que "saúde é uma postura humana ativa e dialética frente às permanentes situações conflituosas geradas pelos antagonismos entre o homem e o meio", considerando que essa relação (seja entre o ser humano e o meio, seja entre os próprios seres humanos) se dá no campo social, cujo trabalho é o ponto de partida.

Diante disso, conforme já indicado em outros textos (SOUZA; SILVA; SILVA, 2013; SOUZA; MELO; VASCONCELLOS, 2015; SOUZA, 2016a; SOUZA, 2016b), o processo saúde-doença só pode ser explicado mediante a

\footnotetext{
${ }^{5}$ Consoante lembra Souza (2016b), para a OMS, a saúde não é apenas a ausência de doença, mas o completo bem-estar físico, psíquico e social. Tal conceito é tautológico, pois apenas diz que saúde é igual a bem-estar, sem especificar o que isso seria. Além disso, é uma perspectiva absolutista, manifestada no uso do adjetivo "completo". Com isso, anula-se a dinamicidade do processo saúde-doença, caindo na mesma dicotomia da concepção biomédica (ou sem tem bemestar ou se tem mal-estar - não há processo).
}

TrabalhoNecessario - www.uff.br/trabalhonecessario; Ano 15, № 27/2017 
indissociabilidade entre o biológico (natural) e o social - caráter que é originário da própria natureza do "ser social". Assim, é preciso

[...] apreender a saúde numa perspectiva da totalidade, considerando-se [...] a dimensão social da saúde sem ignorar a importância de sua base biológica, de caráter insuprimível, assim como sua dimensão singular/individual, ainda que a predominância ontológica seja coletiva/social. Tal conclusão não é fruto da epistemologia, mas uma determinação que emerge da natureza ontológica do ser social, porquanto, conforme Lukács (2013) revelou, o homem ascende à condição de ser social, mas nunca abandona, em absoluto, a condição de ser natural. (SOUZA, 2016b, p. 344).

Assim como o "ser social" não prescinde, em sua estrutura geral, da esfera biológica, todas as suas formas particulares, como no caso da saúde, mantêm essa condição geral. Conforme apontam Tambellini e Câmara (1998, p. 51),

[...] a visão de saúde construída a partir da Saúde Coletiva é bastante ampla, levando em conta dimensões biológicas, sociais, psíquicas e ecológicas, trabalhando e articulando as faces individual e coletiva que correspondem respectivamente à doença vivida pelo doente e ao processo saúde-doença. Portanto, procura-se olhar a saúde, enquanto questão, a partir de uma Medicina Social que vai entender este processo pensando a produção e distribuição de agravos à saúde em suas várias formas, dimensões e conteúdos presentes na sociedade.

Essa é a premissa básica que dá origem ao campo da Saúde Coletiva, com bases na Medicina Social latino-americana. A determinação social da saúde é seu mote teórico, abrindo o horizonte para intervenções na saúde com caráter coletivo, por meio das políticas sociais e pela atuação dos movimentos sociais e outras instâncias da sociedade civil.

Apesar disso, a área da Saúde Coletiva não se desenvolve de forma homogênea, afastando-se continuamente do seu mote teórico originário, ainda que sob um discurso tergiversador. Em especial, isso ocorre a partir da teoria dos Determinantes Sociais da Saúde (DSS), que ganha força na década de 1990. Conforme aponta Nogueira (2009), essa perspectiva reconhece que a saúde possui uma dimensão social, mas fragmenta essa dimensão em diversos fatores (determinantes) que pouco dialogam entre si, substituindo a noção de TrabalhoNecessario - www.uff.br/trabalhonecessario; Ano 15, № 27/2017 
determinação (ou seja, de processo) pela de determinantes (fatores, fragmentos). Sobre isso, Souza, Silva e Silva (2013, p. 54) são enfáticos:

\begin{abstract}
Assim, no nosso modo de ver, a determinação é essencialmente econômica, pois os supostos DSS consistem em condições sociais com raízes materiais precisas, que apenas vão adquirindo novas formas de acordo com o momento histórico vivido pelo sistema do capital, mas que não deixam de compor uma questão una. Todavia, não desconsideremos todas as mediações existentes entre a totalidade social e a singularidade da categoria saúde, dentro do "complexo de complexos", tal qual define Lukács (1981). Do contrário estaríamos fadados a uma determinação linear e mecânica.
\end{abstract}

Nessa perspectiva, pode-se perceber que existem formas diferentes de a saúde se expressar a partir das particularidades sociais que os indivíduos e as coletividades experimentam. A determinação social da saúde revela-se um processo com unidade, embora heterogêneo, e suas variadas maneiras de se manifestar só podem fazer sentido no interior de uma totalidade social fundada pelo trabalho. Sua essência reside em ser produzida e reproduzida, a todo momento, na processualidade histórica do "ser social", enquanto sujeito que transforma o mundo e, ao mesmo tempo, se transforma.

Devido a esse caráter dinâmico, devem-se observar as mediações particulares que incidem sobre a saúde-doença de cada classe, estrato de classe ou grupo social, sem perder de vista a totalidade. Por esse prisma é que se avança no entendimento da saúde das mulheres negras, no sentido de não se restringir a procurar suas determinações na genética, na biologia em geral, mas nas processualidades sociais em que estão imersas. Nesse bojo, destacam-se as questões "raciais" e da mulher (debatida, sobremodo, a partir do que se convencionou chamar de "relações de gênero"). É sobre elas que se discute a seguir.

\title{
APONTAMENTOS SOBRE A QUESTÃO RACIAL
}


O "racismo" tem se revelado, ao longo dos séculos, como um problema social crônico, seja nos períodos históricos nos quais ele é aceito como algo natural, seja naqueles em que sofre maiores questionamentos por alguns segmentos sociais, como ocorre nos últimos anos. Faz-se pertinente, portanto, apreender o "racismo" como categoria teórica a ser debatida, o que implica considerar o conceito de "raça" como particularidade do "ser social"6.

A discussão sobre "raça" tem início no ano de 1684, com uma publicação antropológica do médico francês François Bernier, intitulada Nova divisão da terra pelas diferentes espécies ou raças que a habitam. Mais tarde, em 1758, o sueco Carolus Linnaeus, tido como o "pai da taxonomia moderna", funda o conceito das quatro "raças", baseando-se na origem geográfica do indivíduo e na cor da pele, a saber: Americanus (Homo sapiens americanus: vermelho, mau temperamento e subjugável); Asiaticus (Homo sapiens asiáticos: amarelo, melancólico e ganancioso); Africanus (Homo sapiens afer: preto, impassível e preguiçoso) e Europeus (branco, sério e forte). Essa diferenciação adquire maior expressão a partir da publicação do Ensaio sobre as desigualdades das raças humanas, de Arthur de Gobineau, entre 1835 e 1855, na qual se argumentava que essa desigualdade seria um produto histórico da dinâmica inerente às "raças" (SANTOS et al., 2010).

Em outra perspectiva, segundo Santos et al. (2010), as diferenças genéticas entre as supostas "raças" são consideradas pouco relevantes. O autor anota que, atualmente, sabe-se que o genoma humano é composto de 25 mil genes. As diferenças mais aparentes (cor da pele, textura dos cabelos, formato do nariz) são determinadas por um grupo insignificante de genes. Por exemplo, as diferenças entre um negro africano e um branco nórdico compreendem apenas 0,005\% do genoma humano.

Há um amplo consenso entre antropólogos e geneticistas humanos de que, do ponto de vista biológico, "raças" humanas não existem. Para Guimarães (2006), "raça" é um conceito que não corresponde a nenhuma realidade natural.

\footnotetext{
${ }^{6}$ Aqui, tomamos a concepção de "ser social" em Lukács (2013) como um patamar "superior" do "ser", engendrado no salto ontológico possibilitado pelo trabalho. O humano, ao trabalhar (ao transformar a natureza), se complexifica, ascendendo ao patamar de "ser social" e, portanto, afastando-se continuamente das barreiras naturais.
}

TrabalhoNecessario - www.uff.br/trabalhonecessario; Ano 15, № 27/2017 
Trata-se de um conceito que denota tão somente uma forma de classificação social, baseada numa atitude negativa em relação a certos grupos sociais.

Diante do exposto, admitir que a "raça negra" existe seria concordar com o estudo de Linnaeus e afastar-se das descobertas atuais da ciência, já que "raça" é um termo de conotação social pejorativa. Em contrapartida, o termo etnia referese a um conjunto de expressões culturais comuns de um povo. Portanto, pensar uma etnia negra é pensar um grupo de pessoas que se identificam e são identificadas com o acúmulo de experiências daquilo que tem sido vivido, nesse caso, pelos homens e mulheres negras. É, dessa forma, pensar e compartilhar com os próximos uma origem em comum, uma história, valores, práticas e representações (SILVA; SOARES, 2011).

Além disso, convém destacar a concepção lukacsiana de "gênero humano", porquanto dela se depreende uma noção de totalidade do "ser social" sem as segmentações construídas pelas ideologias favoráveis às desigualdades sociais. A concepção de "gênero humano" se opõe à de "raça", como produto da consubstanciação do "ser social" no salto ontológico dado a partir do trabalho (SILVA, 2012). O termo "gênero humano" prevê um sentido de igualdade entre os humanos, uma vez que a raça humana se constitui como uma unidade de heterogêneos.

Como já mencionado, o "racismo" se arrasta ao longo dos séculos como um problema ora explícito e inaceitável, ora abafado e maquiado. Na época do sistema colonial, ele era explícito e bem-aceito como uma integração natural da vida e da sociedade. Os homens e mulheres negros, na verdade, não eram vistos como humanidade, mas pelo viés da animalidade ou, apenas, como meros instrumentos de trabalho utilizados ao bel-prazer dos senhores das terras nas sociedades pré-capitalistas (MARX, 1988).

O processo de acumulação primitiva do capital teve participação decisiva na exploração da força de trabalha dos negros escravos (sobretudo nas colônias que abasteciam o circuito mercantil de suas metrópoles), fazendo-se valer da premissa da inferioridade natural desta etnia. Segundo Marx (1988), esse escravismo colonial impulsionou o comércio e a indústria burgueses, tendo, como 
uma das particularidades, um processo de "divisão racial" da sociedade acoplado à divisão de classes.

$\mathrm{Na}$ verdade, os paradigmas e valores sociais racistas não possuem outro objetivo a não ser defender os interesses daqueles que são privilegiados com a diferenciação das "raças", favorecendo, portanto, a reprodução da estrutura social cindida em classes sociais. Tal condição era explícita nas sociedades précapitalistas, sendo refuncionalizada e expandida no capitalismo.

Na segunda metade do século XIX, especialmente depois da proibição do tráfico de escravos, na primeira década de 1800, dá-se gradualmente a abolição da escravatura em vários países, chegando ao Brasil em 1888. Os negros são transformados em trabalhadores livres. Porém, esta liberdade, antes comprometida pelo sistema escravocrata, agora estava restrita pela "cultura racial" (a serviço da economia burguesa) vigente no século XIX. Assim, o estatuto de pureza do sangue limitava o acesso de determinados grupos sociais (como ciganos, indígenas, negros e mulatos) a cargos públicos, eclesiásticos e irmandades religiosas, bem como proibia a titulação de barão e conde para tais grupos (ALBUQUERQUE, 2006).

Fernandes (2008) aborda a questão da integração do negro na sociedade de classes e desvela a sua funcionalidade à constituição do capitalismo brasileiro. A tese de Fernandes sobre a "ordem competitiva" brasileira é bem conhecida: revela como o capitalismo nacional vai se constituindo sem o rompimento abrupto com a arcaica estrutura social, tendo uma direção imposta pelo capital internacional. Tal condição implica a dependência econômica, assim como a formação de uma burguesia e de uma classe trabalhadora peculiares, no interior do que o autor chamou de "circuito fechado", uma vez que se mantém a rígida estrutura social anterior.

Nesse processo, a antiga aristocracia rural vai compor, em grande medida, a nova classe dominante: a burguesia brasileira mantém os antigos privilégios que possuía, sem ter um caráter revolucionário, tal qual aquele presente na burguesia internacional em países de capitalismo clássico. Por outro lado, a classe trabalhadora vai ser composta de modo bastante heterogêneo, com a presença de diversos grupos sociais, alguns recém-chegados e outros remanescentes. 
Fernandes (2008) caracteriza essa heterogeneidade identificando os dois principais grupos: "integrados" e "condenados".

Entre os "integrados" estão aqueles absorvidos pela recente "ordem competitiva" brasileira, principalmente a força de trabalho imigrante submetida a uma relação de trabalho assalariado. Apesar de este grupo também sofrer com a exploração e a superexploração típicas do capitalismo dependente, é o grupo dos "condenados" aquele imerso nas piores mazelas sociais, uma vez que engloba os que são rejeitados pelo mercado de trabalho ou, no máximo, absorvidos de forma precarizada (FERNANDES, 2008). A partir desta condição, começam a ser reveladas a origem e a funcionalidade da marginalização da população negra no (e para o) capitalismo brasileiro.

O fato de o Brasil não passar por um processo revolucionário clássico possibilitou a perpetuação de diversos elementos pertencentes ao Brasil não capitalista, o que Fernandes (2008) chama de "conjugação arcaico-moderna". Tais elementos tanto dizem respeito aos privilégios estamentais das antigasnovas classes dominantes, quanto às restrições postas aos diversos grupos sociais. Desta forma, alguns elementos basilares do Brasil colônia vão persistir, sendo redefinidos no Brasil capitalista. É o que acontece com a "questão racial", transmutada de trabalho escravo para processo de "condenação", marginalização e lumpenização dos negros.

Enquanto base do Brasil colônia, o trabalho escravo carregava a concepção de que a "raça negra" seria inferior e, portanto, merecedora da escravização. Com a abolição da escravatura e outras transformações que possibilitaram a constituição do capitalismo brasileiro, o trabalho escravo deu espaço ao trabalho assalariado. Todavia, a concepção de inferioridade da etnia negra persistiu de modo a diferenciar a posição que os negros deveriam ocupar na "ordem competitiva", restringindo seu acesso ao assalariamento. A população negra, então, passa a compor uma fileira de desempregados imersa no pauperismo absoluto, na zona urbana das grandes cidades brasileiras ou, então, submetida aos empregos precários, alguns até sob a forma de trabalho précapitalista, na zona rural (FERNANDES, 2008). 
Essa condição estabelece 0 cenário adequado para o capitalismo subdesenvolvido e rapinante. O grande contingente de "condenados" (em grande medida, negros) viabiliza a extração da mais-valia extraordinária (IANNI, 1981), seja diretamente, pela superexploração de sua força de trabalho, seja exercendo o papel de exército industrial de reserva, o que resulta no rebaixamento dos salários e das condições de trabalho daqueles trabalhadores "integrados".

Por tais razões, o "racismo", já marcante no Brasil colônia, ao ser redefinido e incorporado pelo capital, passa a ser bastante funcional ao se constituir num dos pilares da estratificação da classe trabalhadora e da garantia dos antigos privilégios da classe dominante. O "racismo" comparece, deste modo, tal um mecanismo de defesa dos interesses econômicos, políticos e ideológicos da classe dominante, além de ser um elemento indispensável para a forma peculiar de acumulação de capital no Brasil.

Segundo Albuquerque (2006), neste mesmo processo se encontra a gênese das periferias, dos quilombos, das péssimas condições de salário, dos cortiços, e uma concepção sanitária racista que transforma os negros em "classe perigosa" para a saúde. Todavia, como requer respostas sociais, na década de 1970 surgem processos de mobilização da etnia negra preocupada com a marginalização e a discriminação que enfrentava, reivindicando direitos sociais e transformações culturais.

Nessa época, surge também o conceito de "democracia racial", veementemente atacado pelos integrantes do movimento negro originário, pois tal conceito difunde a ideia de que o negro poderia chegar a se comportar como o branco e gradativamente ser incorporado às elites. A redução do "antirracismo" ao "antirracialismo" e sua utilização para negar os fatos de discriminação e as "desigualdades raciais" crescentes no país acabaram por formar uma "ideologia racista", ou seja, uma justificativa da ordem discriminatória e das "desigualdades raciais" realmente existentes. Em outras palavras, não se mirava a integração/valorização da etnia negra na sociedade, mas seu ajustamento aos parâmetros definidos pela elite branca (burguesa) (GUIMARÃES, 2006).

Mais recentemente, houve até concessões no sentido de incorporar os negros ao mercado de trabalho, o que, na verdade, apenas fez com que o 
"racismo" assumisse uma nova faceta, configurando-se no que, hoje, é chamado de "racismo institucional". Essa forma de "racismo" diz respeito à administração desigual dos melhores postos de trabalho e salários entre os estratos da classe trabalhadora. O "racismo institucional" explicita-se nos salários mais baixos que a população negra recebe, nas relações humanas, no ambiente de trabalho, na dificuldade de acesso à educação superior e à educação básica, e nos serviços de saúde.

Trata-se de um problema enraizado na cultura brasileira e reflete a face rudimentar do nosso capitalismo e, mais do que isso, manifesta a contradição de um país que se diz democrático do ponto de vista étnico e/ou cultural. $\mathrm{Na}$ verdade, o Brasil tenta corrigir suas questões através da criação de políticas afirmativas, como é o caso das políticas públicas de saúde e educação, que se destinam a corrigir uma história de desigualdades e desvantagens sofridas por um grupo étnico em face de um Estado nacional que o discriminou (LÓPEZ, 2012). Contudo, a base material de acumulação do capitalismo dependente permanece intocada, sustentando a desigualdade de classe, que, por sua vez, encontra diversos canais particulares para se expressar, mediante a dominação de "raça".

Assim, toda a produção de riquezas, com a exploração e a dominação que Ihe são peculiares no capitalismo, está associada às relações de poder, a exemplo da dominação "racial" (étnica). No caso da mulher negra, além da subordinação da cor, tem-se a construção de uma ideia de inferioridade ligada ao "gênero feminino", na qual a masculinidade oprime a feminilidade, amplificando a problemática. Sobre esta questão mais específica, trata-se a seguir.

\section{A "QUESTÃO DA MULHER": AS DETERMINAÇÕES DA DOMINAÇÃO/OPRESSÃO DE "GÊNERO"}

A opressão que as mulheres vêm sofrendo está diretamente associada a um entendimento que assegura a superioridade do homem sobre a mulher, apenas por ser homem, o que implica a constituição de um esquema de dominação-exploração (SAFFIOTI, 2010). 
Desta situação desfavorável historicamente estabelecida para as mulheres, surgem as discussões no campo de "gênero". Desse modo, o conceito de "gênero" surge da tentativa de compreender como a subordinação é reproduzida e a dominação masculina é sustentada em suas múltiplas manifestações, buscando incorporar as dimensões subjetiva e simbólica de poder, para além das fronteiras materiais e das conformações biológicas (ARAÚJO, 2010).

O conceito de "gênero" constitui um marco dos estudos sobre a "questão da mulher", com forte contribuição do movimento feminista. Visa elucidar que as atividades, comportamentos e potencialidades tipicamente masculinas e femininas são, na verdade, criadas e repassadas socialmente entre gerações.

No interior da tradição marxista, busca-se compreender o conceito de "gênero" a partir das relações sociais de produção, o que implica aceitar que a realidade determina a subjetividade, e não o contrário (LUKÁCS, 2012). Isso significa dizer que aqueles aspectos que causam prejuízos ao desenvolvimento humano da mulher possuem uma raiz econômica. Frisa-se que, com essa afirmação, não se está a excluir as relações subjetivas entre as pessoas, nem a importante determinação da esfera cultural nesse processo; apenas se enfatiza que existe uma determinação predominante que é de caráter econômico e que, portanto, delimita o campo no interior do qual a "desigualdade de gênero" se desenvolve (CASTRO, 2010).

Desse modo, objetiva-se refletir sobre como os aspectos da subordinação sofrida pelo "gênero feminino" têm afetado direta ou indiretamente a saúde da mulher. Para isto é necessário compreender como o homem e a mulher se constituem como sujeitos sociais. O marxismo vem dando contribuições decisivas para o alcance desse objetivo.

Uma dessas contribuições está no desvelamento da origem e da função social da família monogâmica ${ }^{7}$, dentro da qual se desenvolve a opressão sofrida pelas mulheres. Nesse quesito, cabe citar Engels (2010) em A origem da família, da propriedade e do Estado, que traz uma crítica ferrenha à família monogâmica

${ }^{7}$ Referência à família em geral do tipo capitalista; a família monogâmica apenas representa a forma predominante.

TrabalhoNecessario - www.uff.br/trabalhonecessario; Ano 15, № 27/2017 
como o núcleo celular do sistema capitalista, responsável por proteger e perpetuar a propriedade privada dos homens da classe dominante.

Sobre isso, Moraes (2000, p. 1) destaca que,

No tocante à "questão da mulher", a perspectiva marxista assume uma dimensão de crítica radical ao pensamento conservador. Em A origem da família, da propriedade privada e do Estado, a condição social da mulher ganha um relevo especial, pois a instauração da propriedade privada e a subordinação das mulheres aos homens são dois fatos simultâneos, marco inicial das lutas de classes.

Assim, Engels (2010) demonstra que, através da separação da sociedade em famílias monogâmicas ${ }^{8}$, ocorrem a consubstanciação e a diferenciação da função social do homem e da mulher e, portanto, estabelece-se a opressão daquele sobre esta. Ao resgatar o processo histórico, esse autor descreve a vida nas comunidades primitivas, quando há um intenso convívio coletivo devido à inexistência da propriedade privada. Com o aparecimento do excedente econômico, das classes sociais e da propriedade privada, a sociedade passa a ser organizada de modo diferente, baseada na separação em pequenos grupos reunidos ao redor da propriedade privada: a família. Esta instituição social passa por diversas formas históricas, com vários sistemas de parentesco, até atingir a forma atualmente predominante: a família monogâmica.

Engels (2010, p. 86-7) assevera que

Essa foi a origem da monogamia, tal como pudemos observá-la no povo mais culto e desenvolvido da Antiguidade [os gregos]. De modo algum foi fruto do amor sexual individual, com o qual nada tinha em comum, já que os casamentos, antes como agora, permaneceram casamentos de conveniência. Foi a primeira forma de família que não se baseava em condições naturais, mas econômicas, e concretamente no triunfo da propriedade privada sobre a propriedade comum primitiva, originada espontaneamente. Os gregos proclamavam abertamente que os únicos objetivos da monogamia eram a preponderância do homem na família e a procriação de filhos que só pudessem ser seus para herdar dele.

\footnotetext{
${ }^{8}$ Não se trata de uma crítica à identificação entre as pessoas baseada nos laços consanguíneos, mas de uma crítica ao isolamento das pessoas em pequenos grupos, a fim de fazer prevalecer os interesse privados sobre os coletivos, tendo como base disto a propriedade privada.
}

TrabalhoNecessario - www.uff.br/trabalhonecessario; Ano 15, № 27/2017 
Por conseguinte, o isolamento do ser humano nesse pequeno grupo de caráter burguês tem determinações econômicas; trata-se de uma exigência posta pela dinâmica da propriedade privada. Assim, o homem, possuidor dos meios de produção, necessitava (e necessita) proteger a sua propriedade contra o resto da sociedade, garantindo a herança de seus sucessores. Conforme argumenta Lessa (2012), a união de um homem com uma mulher (que passa a ser "sua") ocorre devido à necessidade da legitimidade social dos seus descendentes, rebaixando a mulher à posição de subordinação, isolada (muito mais do que o homem) da vida coletiva, o que a coloca numa condição desfavorável, restrita à organização da vida doméstica e à criação dos filhos (sucessores). Logo,

A monogamia não aparece na história, portanto, absolutamente,
como uma reconciliação entre o homem e a mulher e, menos
ainda, como a forma mais elevada de matrimônio. Ao contrário,
ela surge sob a forma de escravidão de um sexo pelo outro, como
proclamação de um conflito entre os sexos, ignorados, até então,
na pré-história. (ENGELS, 2010, p. 87).

Cabe esclarecer que isso não quer dizer que o amor sexual individual entre um casal não possa existir, mas que esse encontra suas possibilidades restringidas (por vezes, suprimidas) diante da função primordial do casamento monogâmico na sociedade de classes. Não obstante, a família monogâmica "é a forma celular da sociedade civilizada, na qual já podemos estudar a natureza das contradições e dos antagonismos que atingem seu pleno desenvolvimento nessa sociedade" (ENGELS, 2010, p. 87).

Instituem-se as condições ideais para o homem exercer seu poder sobre a mulher e os filhos ao longo da história. Isso implica um grande entrave ao desenvolvimento humano da mulher $e$ das crianças. $O$ fato de a contemporaneidade revelar enormes variações da forma clássica da família monogâmica corresponde, tão somente, à crise pela qual passa o próprio capital. Com a sua crise estrutural, o sistema do capital presencia a reprodução desta crise no interior de suas instituições, inclusive na família.

No entanto, apesar da crise, a família, onde ela ainda resiste numa forma aproximada aos moldes clássicos descritos por Engels, continua a ser a unidade TrabalhoNecessario - www.uff.br/trabalhonecessario; Ano 15, № 27/2017 
celular econômica que legitima e perpetua a propriedade privada; e a mulher, mesmo que sob a ilusão dos avanços no campo do mercado e das conquistas jurídico-políticas, permanece sendo oprimida pelo homem a partir de formas ainda mais sofisticadas, permitindo que elas sejam mais uma fonte de extração de maisvalia, ao se converterem em força de trabalho massiva.

Sobre isso, diz Lessa (2012, p. 79):

Na primeira década do século 21, pela primeira vez, a maioria das famílias estadunidenses não é mais a família burguesa típica: o marido como provedor, a esposa e as crianças - com a prostituição como apêndice. Variações da organização familiar vão se tornando cada vez mais frequentes: casais homossexuais, famílias em que a esposa é provedora e, bem atrás nas estatísticas, famílias compostas somente pelo pai e pelos filhos. Uma quantidade crescente de casais - hétero ou homossexuais opta por não ter filhos. E, desde pelo menos a Segunda Grande Guerra, mas possivelmente antes, a família vai deixando de ser a unidade econômica decisiva até mesmo na agricultura, um processo que tem seu fundamento na concentração de capitais inerente ao modo de produção capitalista.

Apesar disto, o autor alerta:

Independentemente de serem homens ou mulheres os responsáveis pelas tarefas domésticas, tais responsáveis continuam sendo portadores de possibilidades limitadas, rebaixadas, de crescimento das suas pessoas (as alienações). E, por isso, nem a maternidade nem a paternidade, nem a condição de filhos, podem ser mediações para o pleno desenvolvimento dos indivíduos - independentemente de como as mulheres adentram ou saem do mercado de trabalho e de uma maior ou menor equidade na divisão das tarefas domésticas e de criação dos filhos pelos membros da família (irmãos mais velhos, inclusive). Tais novidades quase imediatamente se convertem em renovados obstáculos ao desenvolvimento dos indivíduos: as relações intrafamiliares espontaneamente reproduzem e reforçam a concorrência e o individualismo, a cotidiana violência doméstica se mantém, continua o abuso sexual de crianças e adolescentes (principalmente por parentes!), intensifica-se a dupla jornada de trabalho por obra e graça da reestruturação produtiva (Hirata, 2002) - numa lista que poderia prosseguir por muito mais. (LESSA, 2012, p. 85).

Ou seja, o que está sendo colocado em xeque é uma forma de organizar a sociedade em pequenas unidades celulares que protegem e perpetuam a

TrabalhoNecessario - www.uff.br/trabalhonecessario; Ano 15, № 27/2017 
propriedade privada, restringindo, assim, o pleno desenvolvimento humano. Historicamente, esse impedimento vem incidindo com maior intensidade sobre as mulheres. Tal condição faz parte do processo de desumanização em geral provocado pela lógica do capital e coloca a necessidade urgente de reação da humanidade contra tal lógica e suas particularidades, como, por exemplo, a "questão da mulher".

Os múltiplos papéis desempenhados pela mulher, nos dias de hoje, representam a história das lutas pela emancipação, igualdade social, política, econômica, educacional etc. Entretanto, esse empreendimento, diversificado e incessante, encontra barreiras culturais fortemente internalizadas, barreiras que inviabilizam atribuir à participação feminina, tanto no mercado de trabalho quanto no ambiente doméstico, o devido valor e reconhecimento. Assim, apesar de todas as discussões e avanços, a mulher ainda é triplamente responsabilizada, pois é ela a principal cuidadora dos filhos, da casa e, muitas vezes, a única provedora do lar. Para o mundo feminino, trabalhar fora de casa consiste numa forma de emancipação; já para o sistema capitalista, é mais uma fonte de sobre trabalho.

De fato, tais questões deparam-se com a factível realidade do argumento da naturalidade para explicar a "questão da mulher" (negra), o que justificaria, por si só, todo o contexto de desigualdade que as rodeia, porquanto sejam tidas como um "tipo" de ser humano inferior, menos qualificado. Daí acreditar-se que o conceito de "gênero" por si só (a partir da matriz teórica que se originou) não abrange a realidade estrutural de opressão que o sistema econômico do Brasil acaba por produzir. Tais estudos, em sua maioria, bem-intencionados e partícipes da luta contra o patriarcalismo, tendem a elevar o "gênero" a um patamar que anula as determinações fundantes das desigualdades capitalistas, empreendendo um debate que confere caráter autônomo a tal questão, como se ela se originasse e se encerrasse em si mesma (SOUZA; SILVA; PEREIRA, 2013)

Isso, em alguma medida, ocorre mesmo entre aqueles que tentam discutir essa questão a partir da perspectiva materialista histórico-dialética, mas deixam escapar a concepção de "gênero humano". Em vez disso, seria mais coerente entender a "questão da mulher" pelo prisma do processo de particularização do "ser social" (em geral) em "ser feminino" e "ser masculino", com elementos 
mutantes ao longo da história, mas compondo um único (porém, heterogêneo) "gênero" (humano) (SOUZA; SILVA; PEREIRA, 2013).

Com efeito, a subordinação imposta à mulher negra é dupla em seu caráter social, visto que tal subordinação se dá pelo fato de ser mulher e, novamente, por ser negra, mas é una em seu caráter econômico, tendo em vista o fio condutor material que une as várias formas de desigualdade sociais no capitalismo. Diante de tudo isso, entender a gênese do "ser social" e as determinações que, no capitalismo, levam-no a se consubstanciar com mediações que parecem fragmentar o "gênero humano", é imprescindível para a real equalização das problemáticas sociais, possibilitando seu enfrentamento desde suas raízes. Portanto, a questão da saúde se revela como uma expressão do caráter destrutivo do capital ante o "gênero humano". Entender este último como totalidade é fundamental para que se apreendam as efetivas bases do processo saúde-doença.

\section{CONSIDERAÇÕES FINAIS}

A saúde das mulheres negras não pode ser explicada apenas pelos fatores genéticos, naturais, biológicos. Tal perspectiva é extremamente limitada, deixando escapar a processualidade histórico-social por trás de tal questão. Esse viés - de biologização da saúde -, em última instância, é o mesmo que sustenta as concepções "racistas" e "machistas" que definem os negros(as) e as mulheres em geral como seres humanos naturalmente inferiores.

Em uma perspectiva contrária, constata-se que existe um processo de determinação social, com preponderância material, nas bases da questão da saúde das mulheres negras. Demonstra-se que a saúde se constitui como particularidade do ser social e, por isso, é determinada, sobretudo, pelo trabalho. No capitalismo, há uma sociedade desigual e problemática porque fundada por uma forma de trabalho de mesmo caráter.

A desigualdade de classes, constituída na esfera econômica, revela-se central para explicar a questão da saúde. Porém, ela por si só não é suficiente.

TrabalhoNecessario - www.uff.br/trabalhonecessario; Ano 15, №27/2017 
Deve-se direcionar, também, considerável atenção para as particularidades de cada processo social particular, pois se percebe que, no caso aqui estudado, as questões "racial" e da mulher são mediações com elementos ímpares.

A questão "racial" constitui um importante elemento para naturalizar a exploração econômica de grupos sociais tidos como inferiores, desde as sociedades pré-capitalistas. No capitalismo, de forma amplificada, essa questão permite criar um sistema de estratificação da classe trabalhadora, funcional à reprodução do capital associada a certos privilégios culturais das velhas-novas classes dominantes, a exemplo do que ocorre no Brasil. A questão da mulher, por sua vez, tem suas origens no seio da família monogâmica constituída ao redor da propriedade privada e, por conseguinte, determina a posição dominante dos homens sobre ela.

Assim, conclui-se que as peculiaridades presentes nessas questões não garantem a autonomia absoluta delas em relação à esfera econômica burguesa. Ao contrário, há uma determinação recíproca e funcional ao sistema de exploração/dominação do capital. O entrelaçamento de tais elementos sobre um mesmo plano de fundo atua de forma sinérgica sobre a saúde das mulheres negras, expressa nos indicadores negativamente diferenciados aqui já apresentados. Por fim, lutar contra as formas particulares de desigualdade social é imperativo para a construção de uma luta geral contra o capital e pela emancipação do "gênero humano".

\section{REFERÊNCIAS}

ALBUQUERQUE, Wlamyra Ribeiro; FILHO, Walter Fraga. Uma história do negro no Brasil. Centro de Estudos Afro-Orientais, Brasília: Fundação Cultural Palmares, 2006.

ARAÚJO, Clara. Marxismo, feminismo e o enfoque de gênero. Crítica Marxista, n. 11, Campinas, 2000.

ATAL, Juan Pablo; ÑOPO, Hugo; WINDER, Natalia. New century, Old Dispatities: Gener and Ethnic Wages Gaps in Latin American. IDB Working Papers Series. New York, n. 109, 2009. 
CASTRO, Mary Garcia. Marxismo, feminismos e feminismo marxista - mais que um gênero em tempos neoliberais. Crítica Marxista, n. 11, Campinas, 2000.

ENGELS, Friedrich. A origem da família, da propriedade privada e do Estado. São Paulo: Expressão Popular, 2010.

FERNANDES, Florestan. A Integração do negro na sociedade de classes: 0 legado da raça braça. Tomo I. 5. ed. São Paulo: Globo, 2008.

GUIMARÃES, Antonio Sérgio Alfredo. Depois da democracia racial. Tempo social, São Paulo, v. 18, n. 2, nov. 2006.

IANNI, Octavio. A ditadura do grande capital. Rio de Janeiro: Civilização Brasileira, 1981.

IPEA. Situação social da população negra por estado. Brasília: Instituto de Pesquisa Econômica Aplicada (IPEA), 2014.

LAURELL, Ana Cristina. La salud-enfermedad como proceso social. Revista Latinoamericana de Salud, Cidade do México, v. 2, 1982.

LESSA, Sergio. Abaixo a família monogâmica! São Paulo: Instituto Lukács, 2012.

LÓPEZ, Laura Cecilia. The concept of institutional racism: applications within the healthcare field. Interface - Comunic., Saúde, Educ. Botucatu, v. 16, n. 40, p. 121-34, jan./mar. 2012.

LUKÁCS, György. Para uma ontologia do ser social I. São Paulo: Boitempo, 2012.

LUKÁCS, György. Para uma ontologia do ser social II. São Paulo: Boitempo, 2013.

MACCACARO, Giulio. Clase y salud. In: BASAGLIA, F; GIOVANNINI, E; MINIATI, S.; PINTOR, L.; PIRELLA, A. et al. La salud de los trabajadores: aportes para una política de salud. México: Editorial Nueva Imagen, 1980.

MARX, Karl. O Capital: crítica da economia política. Livro primeiro, Tomo I. 3. ed. São Paulo: Nova Cultural, 1988.

MORAES, Maria Lygia Quartim. Marxismo e feminismo: afinidades e diferenças. Crítica Marxista, n. 11, Campinas, 2000.

NOGUEIRA, Roberto P. Determinantes, determinação e determinismo sociais.

Saúde Debate, v. 33, n. 83, p. 397-406, 2009. 
REZENDE, Ana Lúcia Magela de. Saúde: dialética do pensar e do fazer. 2. ed. São Paulo: Cortez, 1989.

SAFFIOTI, Heleieth. Quem tem medo dos esquemas patriarcais de pensamento?

Crítica Marxista, n. 11, Campinas, 2000.

SANTOS, Diana Mirelli Cunha Santos. Perfil epidemiológico de pacientes com diabetes mellitus tipo 2 assistidos pelo PSF rural do município de Palmácia CE. 2008. Monografia (Especialização em Diabetes mellitus e Hipertensão Arterial) - Escola de Saúde Pública do Estado do Ceará. Fortaleza, 2008.

SANTOS, Diego Junior da Silva et al. Raça versus etnia: diferenciar para melhor aplicar. Dental Press J. Orthod., Maringá, v. 15, n. 3, Junho, 2010.

SILVA, M L; SOARES, R L S. Reflexões sobre os conceitos de raça e etnia. Entrelaçando. Revista Eletrônica de Culturas e Educação Caderno Temático: Educação e Africanidades N. 4, p. 99-115, 2011.

SILVA NASCIMENTO, Jucian; SARDINHA, Ana Hélia de Lima; PEREIRA, Amanda Namíbia Silva Pereira. Risco cardiovascular em mulheres negras portadoras de hipertensão arterial em uma comunidade de São Luiz - MA. Saúde Coletiva. São Paulo, v. 56, n. 9, p. 40-45, 2012.

SILVA, Uelber B. Racismo e Alienação: uma aproximação à base ontológica da temática social. São Paulo: Instituto Lukács, 2012.

SOUZA, Diego de Oliveira; SILVA, Sóstenes Ericson Vicente da; SILVA, Neuzianne de Oliveira. Determinantes Sociais da Saúde: reflexões a partir das raízes da "questão social". Saúde e Sociedade, São Paulo, v. 22, n. 1, p. 44-56, 2013.

SOUZA, Diego de Oliveira; SILVA, Neuzianne de Oliveira; PEREIRA, Juliane Pereira. Ser masculino e ser feminino: entre a opressão sofrida pelas mulheres e as implicações para a saúde dos homens. In: SOUZA, Diego de Oliveira. Homens \& Saúde: na sociedade do capital. Maceió: Edufal, 2013.

SOUZA, Diego de Oliveira; MELO, Ana Inês Simões Cardoso; VASCONCELLOS, Luiz Carlos Fadel. A saúde dos trabalhadores em 'questão': anotações para uma abordagem histórico-ontológica. O Social em Questão. Rio de Janeiro, v. 18, p. 107;136, 2015.

SOUZA, Diego de Oliveira. Saúde do(s) trabalhador(es): análise ontológica da "questão" e do "campo". Tese [doutorado] em Serviço Social. Programa de PósGraduação em Serviço Social da Universidade do Estado do Rio de Janeiro (UERJ). Rio de Janeiro, 2016a.

SOUZA, Diego de Oliveira. A saúde na perspectiva da 'Ontologia do ser social'. Trabalho, Educação e Saúde (Online). Rio de Janeiro, v. 14, p. 337-354, 2016. 
TAMBELLINI, Anamaria Testa; CÂMARA, Volney de Magalhães. A temática saúde e ambiente no processo de desenvolvimento do campo da saúde coletiva: aspectos históricos, conceituais e metodológicos. Ciência \& Saúde Coletiva, Rio de Janeiro, v. 3, n. 2, p. 47-59, 1998.

Recebido em: 12 de junho de 2017 Aprovado em: 26 de agosto de 2017 Publicado em: 5 de dezembro de 2017 